\title{
Physicochemical Evaluation of Seeds and Oil of Nontraditional Oil Seeds
}

\author{
Adam Ismail Ahmed ${ }^{1 *}$, Awad Mohammed Babeker ${ }^{1}$, Ahmed Mohammed Ahmed Elamin ${ }^{2}$, \\ Elshiekh Awadelkarim Ibrahim ${ }^{3}$
}

\begin{tabular}{l}
${ }^{1}$ Department of Biochemistry and Food Science, Faculty of Natural Resources and Environmental Studies, University of Kordofan, Elobeid, \\
Sudan, P.O. Box.160. \\
${ }^{2}$ Faculty of Veterinary Sciences, West Kordofan University, Gebashe, Sudan \\
${ }^{3}$ Department of Crop Sciences, Faculty of Natural Resources and Environmental Studies, University of Kordofan, Elobeid, Sudan \\
\hline
\end{tabular}

\section{A R T I C L E I N F O}

Article history:

Received 30 April 2015

Accepted 30 July 2015

Available online, ISSN: 2148-127X

Keywords:

Nontraditional

Oil seeds

Chemical

Physiochemical characteristics

${ }^{*}$ Corresponding Author:

E-mail: adamalgnana62@yahoo.com

\section{A B S T R A C T}

The present work was conducted in the Laboratory of Biochemistry and Food science department, Faculty of Natural Resources and Environmental Studies, University of Kordofan, in order to evaluate some nontraditional oil seeds these are i.e. Marula (Sclerocarya birrea), Roselle (Hibiscus sabdariffa L.) seeds and Christ's thorn (Zizyphus spina-christi) seeds. The seeds of the roselle and Christ's thorn fruits were procured from Elobeid local market, North Kordofan State, while marula fruits were obtained from Elnuhod, West Kordofan State. The proximate composition of the seeds, cake and christ's thorn pulp was done. Some chemical and physical properties were performed for the extracted oil. The results revealed that proximate composition of the seeds and cake differ statistically among the studied materials. Significant differences were observed among the oil extracted from these species; moreover, these oils differ significantly in color and viscosity only.

\section{Introduction}

Nontraditional oil seeds of plant species do not only supply oil, but the residual cake could be also used as animal feed or human food (Panhwar, 2005).

Hibiscus is one of the most common flower plants grown worldwide. There are more than 300 species of hibiscus around the world one of them is roselle (Hibiscus sabdariffa $L$.) which is member of plant family malvaceae (Fasoyiro et al., 2005; Ismail et al., 2008; Anonymous, 1970). The different parts of roselle i.e. the seeds, leaves and calyces used as vegetables, source of oils, refreshing drinks and food preserves (Clydescale, 1979). Zizyphus spina-christi L. is a wild tree plant belongs to plant family (Rhamnaceae). The tree is used as a hedge to form defensive fences. The fruit have a sweet edible pulp, the leaves are applied locally to sores, and the roots are used for cure and prevention (Adzu et al., 2001; Adzu et al., 2002).

Marula (Sclerocarya birrea) is member of Anacardiaceae family, Sclerocarya birrea is a common and wide spread indigenous fruit-bearing tree species throughout much of sub-Saharan Africa. It is widely used by rural populations in most countries wherever it grows. Sclerocarya birrea is often referred to as tree of life due to its ability to provide two fundamental human needs namely food and medicine (Orwa et al., 2009; Maroyi, 2013; Street and Prinsloo, 2013).
All parts of the fruit of $S$. birrea are edible. The seeds are high in fat (56-61\%) and protein $(28-31 \%)$. The pulp can be consumed raw or boiled used for sweetening porridge. The nuts, described as a delicacy, are commonly used to supplement the diet during winter or drought periods in countries such as Tanzania and Zambia. Protein contents of 54-70\% have been reported for de-fatted nuts. They are mixed with vegetables or meat or may be pounded and made into a cake before consumption. The nuts yield oil with a quality and fatty acid composition comparable to olive oil but with stability that is 10 times greater. Oil comprises $56 \%$ of the seed. The walnutlike stone contains up to $6 \%$ edible oil, which is occasionally sold on the local market. The oil from the seeds has preservative properties and, if dried and stored in a cool place, meat treated with it is said to keep up to 1 year. Zulu women of South Africa use the extracted oil as a cosmetic (Orwa et al., 2009).

Maroyi (2013) revealed that $S$. birrea is important source of the people livelihood needs fodder, food, fuel wood, medicine, shade, and timber used for making craft. He concluded that the fruit is $100 \%$ edible in raw state, the kernel also $100 \%$ eaten raw or roasted, fruit juice is fermented to produce child beverage, or traditional beer, making jam. The oil processed and added to maize, millet and sorghum porridge, the bark, leaves and roots can be 
used to treat diseases like cold and flu, diarrhea and others.

The higher chemical constituent of nontraditional seeds oil and their cake is particularly important from a nutritional viewpoint. Consumption of such products may be helpful in preventing food deficiency diseases and lead to a better nutritional status of rural people in developing countries where food shortage is widely happened due to many reasons. So the present investigation conducted to analyze oils and cakes produced from marula, roselle and Christ's thorn.

\section{Materials and Methods}

\section{Sample Preparation}

The seeds of the roselle and Christ's thorn fruits were procured from Elobeid local market North Kordofan State, while marula fruits were collected from Elnuhod, West Kordofan State. The fruits of marula crushed using iron mortar and rod, then the woody part was removed to obtain the seed. Christ's thorn fruits dehulled using a sharp knife to obtain the pulp, then crushed to remove the woody part to obtain the seed. Roselle seeds were sorted out and cleaned manually. Samples from each species were milled and taken for analysis. The cake from defatted samples of roselle, Christ's thorn and marula seeds were subjected to proximate composition.

\section{Proximate Composition}

Total nitrogen (micro-Kjeldahl), moisture, oil and ash contents were determined according to AOAC (1990), crude fiber content was determined using acid/alkali digestion method of Southgate (1976), the carbohydrates were calculated by subtraction.

\section{Oil Physicochemical Characteristics}

Acid value and peroxide value were determined according to AOAC (2000), refractive index of the oil was determined according to (ISO, 1960), Iodine value (IV), saponification value and oil color were observed according to the method described by Elalim (2003).

\section{Statistical Analysis}

SPSS 16.00 (Statistical Packages for Social Sciences) was used to analyze data using ANOVA test. Duncan Multiple Range Test (DMRT) was used for mean separation at $(\mathrm{P} \leq 0.05)$.

\section{Result and Discussion}

\section{Chemical composition}

The chemical composition of marula seeds, marula cake, Roselle seeds, Roselle cake, Christ's thorn pulp, Christ's thorn seeds and Christ's thorn cake were presented in Table (1):

The statistical analysis for protein contents in the investigated samples showed that there were significant differences $(\mathrm{P} \leq 0.05)$.

The highest value of protein was found in Christ's thorn cake $(51.03 \%)$, while the lowest value $(4.53 \%)$ was found in marula seeds. The present findings is not in agreement with Elalim (2003) who reported that protein content of Zizyphus spina-christi was $30-32 \%$ in pulp and $4-4.5 \%$ in seeds. The marula seeds protein content (20.35\%) was lower than (27.6, 28.3, 27.6 and 30.9\%) reported by Mojeremane and Tshwenyane (2004) for samples collected from Angola, Botswana, Mozambique and South Africa, respectively. On the other hand marula seeds protein content $(20.35 \%)$ is lower than the value (36.7\% and 56-61\%) reported by Ogbobe (1992) and Orwa et al. (2009). Marula seeds cake protein contents $(38.0 \%)$ was higher than the values reported by Mojeremane and Tshwenyane (2004), but lower than the values (54-70\%) reported by Orwa et al.(2009) who worked in de-fatted nuts. The protein content of Peanut was ranged between 35.97- 36.93\% (Özcan and Seven, 2003).

The analysis of variance for oil contents showed that there were significant differences $(\mathrm{P} \leq 0.05)$ among the investigated samples. The oil content of the samples were $60.9,20.84,23.43,11.53,9.72,28.89$ and $12.33 \%$ for marula seeds, marula cake, Roselle seeds, Roselle cake, Christ's thorn pulp, Christ's thorn seeds and Christ's thorn cake, respectively. The Zizyphus spina-christi seeds oil content was lower than $(32.5 \%)$ reported by Elalim (2003). Marula seeds oil content was very high when compared with the value $(11 \%)$ reported by (Ogbobe, 1992). Shad et al (2012) reported that the oil content of peanut ranged between 45.09-51.63\%, while that reported by (Özcan and Seven, 2003) showed that the oil content of peanut were $31.52-44.09 \%$. The oil contents extracted from white and red sesame seeds were 48 and 50, respectively (Mohammed and Hamza, 2008).

Table 1 The chemical composition of some nontraditional seed oil plants

\begin{tabular}{l|rrrrrr}
\hline \multicolumn{1}{c|}{ Crop } & \multicolumn{1}{c}{ Protein \% } & \multicolumn{1}{c}{ Oil\% } & \multicolumn{1}{c}{ Ash\% } & \multicolumn{1}{c}{ Fiber\% } & Carbohydrate\% & Moisture\% \\
\hline Marula seeds & $20.35 \mathrm{~d} \pm 0.06$ & $60.9 \mathrm{a} \pm 0.50$ & $3.4 \mathrm{c} \pm 0.14$ & $6.16 \mathrm{~d} \pm 0.12$ & $6.46 \mathrm{~g} \pm 0.69$ & $2.73 \mathrm{f} \pm 0.09$ \\
Marula cake & $36.67 \mathrm{c} \pm 1.76$ & $20.84 \mathrm{~d} \pm 0.10$ & $7.43 \mathrm{a} \pm 0.13$ & $7.96 \mathrm{c} \pm 0.95$ & $20.30 \mathrm{~d} \pm 1.51$ & $6.80 \mathrm{~b} \pm 0.16$ \\
Roselle seeds & $21.06 \mathrm{~d} \pm 0.11$ & $23.43 \mathrm{c} \pm 0.73$ & $6.59 \mathrm{a} \pm 0.80$ & $14.50 \mathrm{a} \pm 0.4$ & $29.15 \mathrm{~b} \pm 1.15$ & $5.27 \mathrm{~d} \pm 0.32$ \\
Roselle cake & $40.30 \mathrm{~b} \pm 0.72$ & $11.53 \mathrm{f} \pm 0.12$ & $2.55 \mathrm{c} \pm 0.13$ & $12.24 \mathrm{~b} \pm 0.46$ & $23.28 \mathrm{c} \pm 1.28$ & $10.1 \mathrm{a} \pm 0.50$ \\
Christs thorn pulp & $4.53 \mathrm{e} \pm 0.03$ & $9.72 \mathrm{~g} \pm 0.16$ & $6.61 \mathrm{a} \pm 0.83$ & $4.81 \mathrm{e} \pm 0.11$ & $64.50 \mathrm{a} \pm 0.14$ & $5.60 \mathrm{~cd} \pm 0.14$ \\
Christs thorn seeds & $38.79 \mathrm{~b} \pm 0.33$ & $28.89 \mathrm{~b} \pm 0.58$ & $2.88 \mathrm{c} \pm 0.83$ & $3.84 \mathrm{f} \pm 0.42$ & $16.12 \mathrm{e} \pm 0.35$ & $4.20 \mathrm{e} \pm 0.16$ \\
Christs thorn cake & $51.03 \mathrm{a} \pm 0.28$ & $12.33 \mathrm{e} \pm 0.21$ & $4.70 \mathrm{~b} \pm 0.36$ & $7.53 \mathrm{c} \pm 0.20$ & $12.92 \mathrm{f} \pm 0.53$ & $5.90 \mathrm{c} \pm 0.36$ \\
\hline
\end{tabular}

Data are the means of three independent replicates - Values are means \pm (standard deviation). - Means not sharing a common superscript letter in a column are significantly different at $\mathrm{P}<0.05$ as assessed by Duncan's Multiple-Range Test. 
Table 2 Chemical characteristics of the oil of nontraditional seed oil plants

\begin{tabular}{l|cccc}
\hline Crop & $\begin{array}{c}\text { Saponification value } \\
\text { mg KOH/g oil }\end{array}$ & $\begin{array}{c}\text { Iodine value } \\
\text { g/100g oil }\end{array}$ & $\begin{array}{c}\text { Acid value } \\
\mathrm{mg} / \mathrm{g} \text { oil }\end{array}$ & $\begin{array}{c}\text { Peroxide value meq } \\
\mathrm{O}_{2} / \mathrm{kg} \text { oil }\end{array}$ \\
\hline Marula oil & $(196.35) \mathrm{a} \pm 00$ & $(102.44) \mathrm{a} \pm 1.1$ & $(8.41) \mathrm{a} \pm 00$ & $(000) \mathrm{c} \pm 000$ \\
Roselle oil & $(193.3) \mathrm{b} \pm 0.72$ & $(103.3) \mathrm{a} \pm 0.98$ & $(5.61) \mathrm{c} \pm 00$ & $(6.54) \mathrm{a} \pm 0.76$ \\
Christs thorn oil & $(176.0) \mathrm{c} \pm 0.82$ & $(88.00) \mathrm{b} \pm 0.82$ & $(6.50) \mathrm{b} \pm 0.41$ & $(2.83) \mathrm{b} \pm 0.16 \mathrm{nb}$ \\
\hline
\end{tabular}

Data are the means of three independent replicates - Values are means \pm (standard deviation). - Means not sharing a common superscript letter in a column are significantly different at $\mathrm{P}<0.05$ as assessed by Duncan's Multiple-Range Test.

The statistical analysis revealed that significant differences $(\mathrm{P} \leq 0.05)$ were found among the samples for ash contents. The highest value of ash was found in marula cake $(7.43 \%)$, while the lowest value $(2.55 \%)$ was found in roselle cake. Marula seeds ash content $(3.4 \%)$ is slightly lower than the values reported by Mojeremane and Tshwenyane (2004). The ash content of Christ's thorn seeds $(2.88 \%)$ was lower than the value $(5 \%)$ obtained by Elalim (2003), while Christ's thorn pulp ash content $(6.61 \%)$ was higher than the value $(4 \%)$ reported by (Elalim (2003) for Sudanese Christ's thorn pulp. The ash content for peanut reported by (Özcan and Seven, 2003) was $2.02-2.05 \%$.

Significant differences were obtained among the samples for crude fiber. The mean crude fiber were 6.16 , 7.96, 14.50, 12.24, 4.81, 3.84 and $7.53 \%$ for Marula seeds, marula cake, Roselle seeds, Roselle cake, Christ's thorn pulp, Christ's thorn seeds and Christ's thorn cake, respectively. Marula seeds crude fiber $(6.16 \%)$ in the present work was very high compared with the values $(4.5,2.9,2.8$ and $2.4 \%)$ reported by Mojeremane and Tshwenyane (2004) for samples collected from Angola, Botswana, Mozambique and South Africa and (3.4\%) reported by (Ogbobe, 1992).

The statistical analysis for carbohydrates contents showed significant differences $(\mathrm{P} \leq 0.05)$ among the samples. The carbohydrates content of the investigated samples were 6.46, 20.30, 29.15, 23.28, 64.50, 16.12 and $12.92 \%$ for marula seeds, marula cake, Roselle seeds, Roselle cake, Christ's thorn pulp, Christ's thorn seeds and Christ's thorn cake, respectively. Marula seeds carbohydrates content $(6.46 \%)$ was very low when compared with the value $(17.2 \%)$ reported by (Ogbobe, 1992), but it was higher than the values (Zero, 3.7, 5.3 and $1.5 \%$ ) Mojeremane and Tshwenyane (2004).

The statistical analysis for moisture contents showed that there were significant differences $(\mathrm{P} \leq 0.05)$ among the samples. The moisture content of the samples were 2.73, $6.80,5.27,10.10,5.60,4.20$ and $5.90 \%$ for marula seeds, marula cake, Roselle seeds, Roselle cake, Christ's thorn pulp, Christ's thorn seeds and Christ's thorn cake, respectively.

The Christi's thorn seeds moisture content (4.20\%) were higher than the value $(3 \%)$ reported by Elalim (2003), whereas the moisture content $(5.60 \%)$ found in Zizyphus spina-christi pulp was slightly lower than the value $(5.75 \%)$ reported by Elalim (2003). Marula seeds moisture contents $(2.73 \%)$ was lower than the values of Mojeremane and Tshwenyane (2004).
Chemical characteristics of the oil of nontraditional seed oil plants

The Saponification value, iodine value acid value and peroxide value of marula oil, Roselle oil and Christ's thorn oil were presented in table (2).

Significant differences $(\mathrm{P} \leq 0.05)$ were found between samples for saponification value. The saponification value of the oil samples were 196.35, 193.30 and 176.00 for marula seeds oil, Roselle oil and Christ's thorn oil, respectively. The results in agreement with SSMO (2009) which reported that saponification value of groundnuts oil should be in the range 187-196 and that of sesame oil 187-195. The Saponification value of peanut oil was ranged between 226.40-246.56 (Shad et al., 2012) in same time Hebbani et al (2013) reported the saponification value of peanut was 291.while the Saponification value of the oil extracted from white and red sesame seeds were 189 and 191, respectively (Mohammed and Hamza, 2008) Christ's thorn seeds oil saponification value (176.0) was lower than SSMO (2009) standards and also lower than that (196.35) reported by Elalim (2003). Eltom and Yagoub (2007) reported that the saponification value peanut oil extracted by different methods of extraction was 189.344 .

The analysis of variance showed significant differences between samples for iodine value. The iodine value of the oil samples were 102.44, 103.30 and 88.00 for marula seeds oil, Roselle seeds oil and Christ's thorn seeds oil, respectively the oils iodine value in accordance with SSMO (2009) standards of 80-106 and 104-120 for groundnuts and sesame oils, respectively. The results of Zizyphus spina-christi were higher than the value (82.2) reported by Elalim (2003). Hebbani et al (2013) showed that iodine value of peanut oil was 111.34, Eltom and Yagoub (2007) reported that the iodine value of peanut oil extracted by different methods of extraction was 91.92.

The iodine value of the oil extracted from white and red sesame seeds were 103 and 116, respectively (Mohammed and Hamza, 2008).

The study of Peanut oil iodine value by Shad et al (2012) revealed that the iodine value ranged between $70.16-86.02$.

Significant differences $(\mathrm{P} \leq 0.05)$ were detected among the investigated samples for acid value. The acid value of the oil samples were 8.41, 5.61 and 6.50 for marula oil, Roselle oil and Christ's thorn oil, respectively. The acid values of these oils were not in agreement with SSMO (2009) standards of 4 for groundnuts and sesame oils. Elalim (2003) reported that acid value of Zizyphus spinachristi seeds oil was 6.46. The ranges 3.96- 4.95 were reported by Shad et al (2012) for peanut oil acid value, 
while Hebbani et al (2013) reported that the acid value of peanut was 2.28. The acid value of the oil extracted from white and red sesame seeds were 0.5 and 0.45 , respectively (Mohammed and Hamza, 2008), Eltom and Yagoub (2007) reported that the acid value of peanut oil extracted by different methods of extraction was 0.69 .

There were significant differences $(\mathrm{P} \leq 0.05)$ among the samples for peroxide value. The peroxide value of the oils was 0 for marula oil, 6.54 for roselle oil and 2.83 for Christ's thorn seeds oil. The peroxide values of these oils were in agreement with SSMO (2009) standards of 15 for groundnuts and sesame oils. The peroxide value of the oil extracted from white and red sesame seeds were 8 and 7.45, respectively (Mohammed and Hamza, 2008), while Hebbani et al (2013) showed that peroxide value of peanut oil was 19 .

Elalim (2003) reported that peroxide value of Zizyphus spina-christi seeds oil was 2.25. Eltom and Yagoub (2007) reported that the peroxide value of peanut oil extracted by different methods of extraction was 9.77 .

The peroxide value (zero) of the marula seed oil means that it has high stability character. Philip (2008) stated that marula oil tremendously stable, outperforming all known natural liquid oils. These combinations of high nutritional value and excellent stability make it an ideal and innovative choice for modern cosmetic formula and for other applications where unsurpassed resistances to oxidation are required.

Physical characteristics of the oil of nontraditional seed oil plants

The refractive index, viscosity and oil color of marula oil, roselle oil and Christ's thorn oil were presented in table (3).

There were no significant differences $(\mathrm{P} \leq 0.05)$ among marula, Christ's thorn and roselle seeds oils refractive index. The Refractive indexes of the oils were 1.462, 1.464 and 1.468 for marula oil, roselle oil and Christ's thorn oil, respectively. These findings mean that the refractive index of the oil of nontraditional seeds oil is not affected by the seeds type, the trend was obviously confirmed by the findings of Elalim (2003) who reported that refractive index of Zizyphus spina-christi seeds oil was 1.4678. SSMO (2009) stated that groundnuts oil refractive index should be in the range 1.460-1.465, while that of sesame oil was in the range 1.465-1.469.

Eltom and Yagoub (2007) reported that the refractive index of peanut oil extracted by different methods of extraction was 1.462 .

Significant differences $(\mathrm{P} \leq 0.05)$ were observed among the investigated samples for viscosity. The highest value (60.0) of viscosity was found in roselle oil, while the lowest value (4.4) was found in marula oil. Eltom and Yagoub (2007) reported that the viscosity of the peanut oil extracted by different methods of extraction was 27.42 .

The oil color of the samples were $35 \pm 0$ Y $1.56 \pm 2.3 \mathrm{R}$, $30.3 \pm 0.275 \mathrm{Y} 2.07 \pm 0.03 \mathrm{R}$ and $25.2 \pm 2.95 \mathrm{Y}, 2.1 \pm 0.104 \mathrm{R}$ for marula seeds oil, roselle seeds oil and Christ's thorn seeds oil, respectively.

\section{Conclusion}

The differences in composition of the samples in this study and the later ones might be due to genetic, environmental factors as well as stage of maturity. In this study chemical and physical characteristics of oils of nontraditional seeds were not different from those extracted from traditional seeds oil such as groundnuts, sesame etc. thus it could be used in food, feed and industry. Decortication should be developed for large scale production of oil from marula, roselle and Christ's thorn. Study of fatty acids, amino acids as well as vitamins, organoleptic and panel test of paramount importance from consumer viewpoints.

\section{Acknowledgments}

The authors appreciated the help given by the laboratory staff of biochemistry and food science department, the help given by Dr. Mohamed Abdelmohsin during manuscript preparation is also appreciated.

Table 3 Physical characteristics of the oil of nontradtional seed oils plant

\begin{tabular}{l|ccc}
\hline \multicolumn{1}{c|}{ Crop } & Refractive index & Viscosity centiboise & Oil color\% \\
\hline Marula oil & $(1.462) \mathrm{a} \pm 0.0001$ & $(4.4) \mathrm{c} \pm 0.284$ & $(35) \mathrm{a} \pm 00 \mathrm{Y},(1.56) \mathrm{b} \pm 2.3 \mathrm{R}$ \\
Roselle oil & $(1.464) \mathrm{a} \pm 0000$ & $(62.0) \mathrm{a} \pm 0.163$ & $(30.3) \mathrm{b} \pm 0.275 \mathrm{Y},(2.07) \mathrm{a} \pm 0.03 \mathrm{R}$ \\
Christs thorn oil & $(1.4681) \mathrm{a} \pm 0.0001$ & $(50.25) \mathrm{b} \pm 0.20$ & $(25.2) \mathrm{c} \pm 2.95 \mathrm{Y},(2.1) \mathrm{a} \pm 0.104 \mathrm{R}$ \\
\hline
\end{tabular}

Data are the means of three independent replicates - Values are means \pm (standard deviation). - Means not sharing a common superscript letter in a column are significantly different at $\mathrm{P}<0.05$ as assessed by Duncan's Multiple-Range Test.

\section{References}

Adzu B, Amos S, Wambebe C, Gamaniel, K. 2001. Antinociceptive activity of Zizyphus spina-christi root bark extract, Fitoterapia 72:344-350.

Adzu B, Amos S, Wambebe C, Gamaniel K. 2002. Effect of Zizyphus spina-christi Wild aqueous extract on the central nervous system in mice, Journal of Ethnopharmacology, 79:1316.

Anonymous. 1970. How to grow kenaf for profit. Research Division Rep. MANR, Ibadan, Nigeria.
AOAC. 1990. Official Methods of Analysis, 15th Edn. Association of Official Analytical Chemists, Washington D.C.

AOAC. 2000. Official Methods of Analysis, Association of Official Analytical Chemists, Washington D.C.

Clydescale FM, Main JH, Francis FJ. 1979. Roselle (Hibiscus sadbariffa) anthocyanins as colourants for beverages and gelatin deserts, J. Food Protection, 42: 204-267.

Elalim BE. 2003. Chemical studies on Zizyphus spina-christi fruit, M.Sc.Thesis, Faculty of Education, University of Kordofan, Elobeid, Sudan. 
Eltom OAO, Yagoub AA. 2007. Physicochemical properties of processed peanut (Arachis hypogaea) oil in relation to Sudanese standards : A Case study in Nyala, South Darfur state, Sudan, Journal of Food technology,5 (1):71-76.

Fasoyiro SB, Babalola SO, Owosibo T. 2005. Chemical Composition and Sensory Quality of Fruit-Flavoured Roselle (Hibiscus sabdariffa) Drinks, World Journal of Agricultural Sciences 1 (2): 161-164.

Hebbani AV, Krishnappa SB, Desai SP, Sudhakar T, Nanjundaiah NK, Barnabas J. 2013. Deteriorative Effects of Repeated Boiling on The Nutritive Value of Edible Oils, International Journal of Biological \& Pharmaceutical Research. 4(5): 333339.

Ismail A, Ikram EHK, Nazri HSM. 2008. Roselle (Hibiscus sabdariffa) seeds Nutritional composition, protein quality and Health benefits, Food 2(1):1-16. Global science books.

ISO. 1960. International organization for standardization (ISO) recommendation, R150 RAW/ refined and boiled Lin seed oil $1^{\text {st }}$ Edition.

Maroyi A. 2013. Local knowledge and use of Marula [Sclerocarya birrea (A. Rich) Hochst.] In South-central Zimbabwe, Indian Journal of Traditional knowledge, 12(3):398-403.

Mohammed MI, Hamza ZU. 2008. Physicochemical Properties of Oil Extracts from Sesamum Indicum L. Seeds Grown in Jigawa State - Nigeria, J. Appl. Sci. Environ. Manage. Vol. 12(2) $99-$ 101.
Mojeremane W, Tshwenyane S. 2004. The Resource Role of Marula (Sclerocarya birrea): A Multipurpose Indigenous Fruit Tree of Botswana, journal of biological sciences, 4(6):771-775.

Ogbobe O. 1992. Physico-chemical composition and characterization of the seed and seed oil of Sclerocarya birrea, plant food for human nutrition, 42(3):201-206.

Orwa C, Mutua A, Kindt R, Jamnadass R, Simons A. 2009. Agroforestree Database: a tree reference and selection guide version 4.0 (http://www.worldagroforestry.org/af/treedb/).

Özcan M, Seven S. 2003. Physical and chemical analysis and fatty acid composition of peanut, peanut oil and peanut butter from ÇOM and NC-7 cultivars, Grasas y Aceites Vol. 54. Fasc. 1 (2003), 12-18.

Panhwar F. 2005. Nontraditional oil seeds and oil, Digitalverlag $\mathrm{GmbH}$, Germany, www.chemLin.com.

Philip TK. 2008. Catalysing Market Development, The Magic of Marula, book chapter 9: 232-257.

Shad MA, Pervez H, Zafar ZI, Nawaz H, Khan H. 2012. Physicochemical properties, fatty acids profile and antioxidant activity of Peanut oil; Pak. J.Bot., 44(1):435-440.

Southgate DA. 1976. The analysis of dietary fiber. In: Fiber in Human Nutrition. G. A. Spiller and R. J. Amen (eds.). Plenum Press, New York U.S.A, pp: 73.

SSMO. 2009. Groundnuts and Sesame oils standards, MSDG NO 2009/199 and 0047

Street RA, Prinsloo G. 2013. Commercial important medicinal plant of South Africa, A review, journal of chemistry, 2013, http//doi.org/10.1155/2013/205048. 